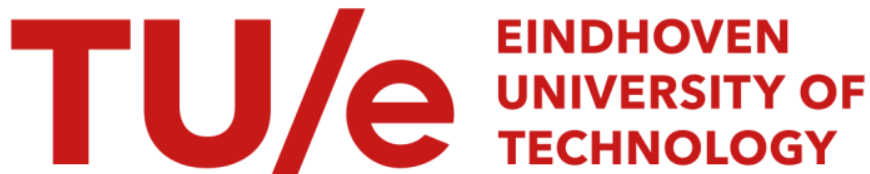

\section{Reactions in the CaO-Cs2O-Al2O3 system at 900 degrees C}

\section{Citation for published version (APA):}

Hoek, van, J. A. M., Loo, van, F. J. J., Wolff, L. R., \& Metselaar, R. (1989). Reactions in the CaO-Cs2O-Al2O3 system at 900 degrees C. Journal of the European Ceramic Society, 5(2), 93-98. https://doi.org/10.1016/09552219(89)90015-0, https://doi.org/10.1162/JEEA.2007.5.1.93

DOI:

10.1016/0955-2219(89)90015-0

10.1162/JEEA.2007.5.1.93

Document status and date:

Published: 01/01/1989

\section{Document Version:}

Publisher's PDF, also known as Version of Record (includes final page, issue and volume numbers)

\section{Please check the document version of this publication:}

- A submitted manuscript is the version of the article upon submission and before peer-review. There can be important differences between the submitted version and the official published version of record. People interested in the research are advised to contact the author for the final version of the publication, or visit the $\mathrm{DOI}$ to the publisher's website.

- The final author version and the galley proof are versions of the publication after peer review.

- The final published version features the final layout of the paper including the volume, issue and page numbers.

Link to publication

\section{General rights}

Copyright and moral rights for the publications made accessible in the public portal are retained by the authors and/or other copyright owners and it is a condition of accessing publications that users recognise and abide by the legal requirements associated with these rights.

- Users may download and print one copy of any publication from the public portal for the purpose of private study or research.

- You may not further distribute the material or use it for any profit-making activity or commercial gain

- You may freely distribute the URL identifying the publication in the public portal.

If the publication is distributed under the terms of Article 25fa of the Dutch Copyright Act, indicated by the "Taverne" license above, please follow below link for the End User Agreement:

www.tue.nl/taverne

Take down policy

If you believe that this document breaches copyright please contact us at:

openaccess@tue.nl

providing details and we will investigate your claim. 


\title{
Reactions in the $\mathrm{CaO}-\mathrm{Cs}_{2} \mathrm{O}-\mathrm{Al}_{2} \mathrm{O}_{3}$ System at $900^{\circ} \mathrm{C}$
}

\author{
Johan A. M. van Hoek, Frans J. J. van Loo, Lodewijk R. Wolff \& Rudı Metselaar
}

Centre for Technical Ceramics, University of Technology, Eindhoven, The Netherlands

(Received 19 January 1989, revised version received 13 July 1989, accepted 25 July 1989)

\begin{abstract}
Reactions in the system $\mathrm{CaO}-\mathrm{Cs}_{2} \mathrm{O}-\mathrm{Al}_{2} \mathrm{O}_{3}$ were investigated On the basis of the experimental results, a compatibility diagram for this system at $900^{\circ} \mathrm{C}$ is proposed In this system a new compound was found and formulated as $\mathrm{Cs}_{2} \mathrm{O} \quad 2 \mathrm{CaO} \quad 4 \mathrm{Al}_{2} \mathrm{O}_{3}$ The $\mathrm{X}$-ray diffraction pattern was measured and the cell parameters were derived

The phase relation results can be used to draw some conclusions about the caesium compatibility of $\mathrm{Al}_{2} \mathrm{O}_{3}$ containing calcia We found that all calcium alumtnates react with $\mathrm{Cs}_{2} \mathrm{O}$ forming a stable compound From these results we conclude that calcum will have a negative effect on the caesium resistance of $\mathrm{Al}_{2} \mathrm{O}_{3}$
\end{abstract}

Es wurden die Reaktionen im System $\mathrm{CaO}-\mathrm{Cs}_{2} \mathrm{O}-$ $\mathrm{Al}_{2} \mathrm{O}_{3}$ untersucht Anhand der experimentellen Ergebnisse wurde ein Kompatibllitatsdiagramm bel $900^{\circ} \mathrm{C}$ aufgestellt In diesem System wurde eine neue Phase gefunden, der die Formel $\mathrm{Cs}_{2} \mathrm{O} 2 \mathrm{CaO} 4 \mathrm{Al}_{2} \mathrm{O}_{3}$ zugeordnet wurde Muttels Rontgenbeugungsdiagrammen wurden die Parameter der Elementarzelle bestımmt

Aufgrund der Ergebnisse konnen Aussagen uber den Einflu $\beta$ von $\mathrm{Cs}$ auf $\mathrm{CaO}$-haltiges $\mathrm{Al}_{2} \mathrm{O}_{3}$ gemacht werden Wir fanden heraus, daß alle Kalziumaluminate mit $\mathrm{Cs}_{2} \mathrm{O}$ unter Bildung einer stabllen Verbindung reagieren Daraus schließen wir, daß Kalzium einen negativen Einflu $\beta$ auf den $C s$-Widerstand von $\mathrm{Al}_{2} \mathrm{O}_{3}$ hat

On a étudié les réactions dans le systèmr $\mathrm{CaO}-\mathrm{Cs}_{2} \mathrm{O}$ $\mathrm{Al}_{2} \mathrm{O}_{3}$ On propose, pour ce système à $900^{\circ} \mathrm{C}$, un schéma de compatibllité basé sur des résultats expérlmentaux On a trouvé dans ce système un composé nouveau de formule $\mathrm{Cs}_{2} \mathrm{O} 2 \mathrm{CaO} \quad 4 \mathrm{Al}_{2} \mathrm{O}_{3}$ Ses paramètres de malle ont été obtenus par diffraction $X$

Les données sur les relatıons de phases permettent de tirer des conclusions sur le comportement vis-à-vis du césium d'une alumine contenant de la chaux Nous avons trouvé que tous les aluminates de calcum réagissent avec $\mathrm{Cs}_{2} \mathrm{O}$ en formant un composé stable Nous en dédutsons que le calcium a un effet négattf sur la résistance au céstum de l'alumine

\section{Introduction}

Only work on one quasi-ternary phase diagram involving $\mathrm{Cs}_{2} \mathrm{O}$ and $\mathrm{Al}_{2} \mathrm{O}_{3}$ has been done in the past, namely on the $\mathrm{Cs}_{2} \mathrm{O}-\mathrm{S}_{1} \mathrm{O}_{2}-\mathrm{Al}_{2} \mathrm{O}_{3}$ diagram ${ }^{1,2}$ This was done because of its importance for the nuclear technology Yet there are some other important applications which merit such an investigation In our own laboratory, work is performed on thermionic energy converters ${ }^{3-5}$ Thermal energy is converted into electric energy by electron emission from a high temperature electrode (emitter) to a low temperature electrode (collector) In order to avold space charge effects caesium vapour is introduced in the interelectrode space Caesium is chosen here because of its low ionization potential For the same reason this element is used in closed-cycle magneto hydrodynamic generators In both applications, materials are exposed to temperatures in the range of $1000-1700^{\circ} \mathrm{C}$ Under these circumstances caesium is highly aggressive and only few materials have a sufficient corrosion resistance A number of research studies have been carried out in the past with the objective of finding such materials ${ }^{6-9}$ Alumina seems to be one of the best The corrosion resistance Is, however, largely determined by the sinter additives and grain boundary phases For instance, silica additions have a detrimental effect ${ }^{10-12}$ Other well known sintering aids for the densification of alumina are magnesia and calcia 
The studies reported so far were always performed by exposing a material for a certain amount of time to caesium vapour at a certain temperature, and examining it afterwards in order to find out whether the material had been damaged or not In this study we want to present some results of a more fundamental approach, that is the phase diagram examination of the $\mathrm{CaO}-\mathrm{Cs}_{2} \mathrm{O}-\mathrm{Al}_{2} \mathrm{O}_{3}$ system In the quasi-binary $\mathrm{Cs}_{2} \mathrm{O}-\mathrm{Al}_{2} \mathrm{O}_{3}$ system, two compounds have been reported in the literature ${ }^{13,14}$ $\mathrm{Cs}_{2} \mathrm{O} \mathrm{Al}_{2} \mathrm{O}_{3}(\mathrm{CsA})$ was made by reactıng $\mathrm{CsNO}_{3}$ with $\mathrm{Al}_{2} \mathrm{O}_{3} \quad 3 \mathrm{H}_{2} \mathrm{O}$ (Throughout this paper $\mathrm{CaO}=$ $\mathrm{C}, \mathrm{Al}_{2} \mathrm{O}_{3}=\mathrm{A}$ and $\mathrm{Cs}_{2} \mathrm{O}=\mathrm{Cs}$ ) $\mathrm{CsA}$ will react with water forming a hydrate $\mathrm{CsA}+4 \mathrm{H}_{2} \mathrm{O} \rightarrow \mathrm{CsA}$ $4 \mathrm{H}_{2} \mathrm{O}^{15}$ Above $550^{\circ} \mathrm{C}$ this reaction will go in the opposite direction The second phase mentioned in this system was $\mathrm{CsA}_{11}$, which is formed by heating CsA for a year at $700^{\circ} \mathrm{C}$ Because this phase is formed only after such a long reaction time and was never found in our experiments, it will not be taken into account in the present study

The quasi-binary system $\mathrm{CaO}-\mathrm{Al}_{2} \mathrm{O}_{3}$ has been the subject of numerous studies, mainly because of its importance to the cement industry The two most recently published phase diagrams are very much alıke (see Fig 1) ${ }^{16,17}$ The stability of $\mathrm{CA}_{6}$ at lower temperatures is a point of discussion This phase is only formed at temperatures above $\pm 1330^{\circ} \mathrm{C}{ }^{18}$ but does not dissociate at lower temperatures ${ }^{19}$ Diffusion couple experiments of $\mathrm{CaO}$ against $\mathrm{Al}_{2} \mathrm{O}_{3}$ at $1330^{\circ} \mathrm{C}$ resulted in formation of all known calcium aluminates The relative amounts of these phases in this diffusion couple were in the order $\mathrm{C}_{12} \mathrm{~A}_{7} \gg$ $\mathrm{C}_{3} \mathrm{~A}>\mathrm{CA}_{6}>\mathrm{CA}_{2} \cong \mathrm{CA}$ Another study showed an increasing amount of $\mathrm{CA}_{6}$ at expense of $\mathrm{CA}$ and $\mathrm{CA}_{2}$ when going to higher temperatures ${ }^{20}$ No studies of the phase diagram were reported at temperatures below $1000^{\circ} \mathrm{C}$

No information was found in the literature on the

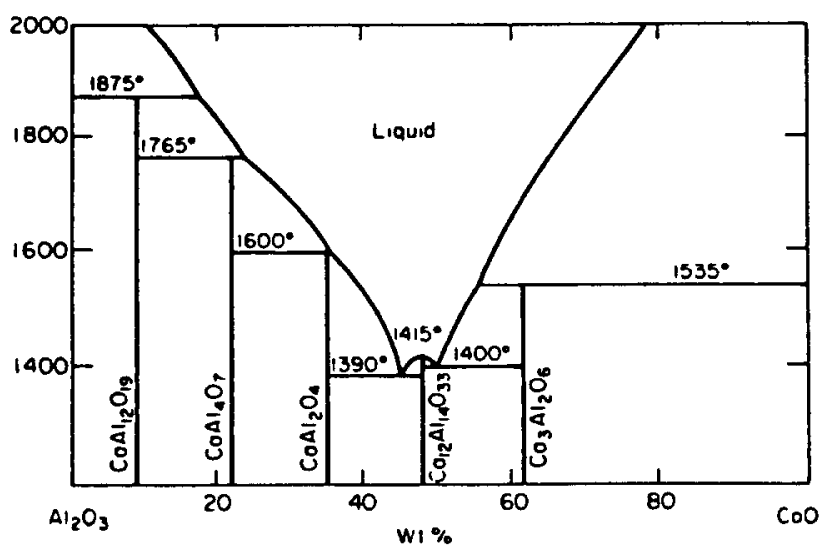

Fig. 1. The $\mathrm{CaO}-\mathrm{Al}_{2} \mathrm{O}_{3}$ system according to $\mathrm{A} \mathrm{K}$ Chatterjee and $G$ I Zhmoidın ${ }^{17}$ quasi-ternary system $\mathrm{Cs}_{2} \mathrm{O}-\mathrm{CaO}-\mathrm{Al}_{2} \mathrm{O}_{3}$ nor on the $\mathrm{Cs}_{2} \mathrm{O}-\mathrm{CaO}$ system

\section{Experimental}

The startıng materials were $\mathrm{Cs}_{2} \mathrm{CO}_{3}$ (FO Optıpur, $>998 \%$, E Merck AG, Darmstadt, FRG), $\mathrm{CaCO}_{3}$ (Zur Analyse, $>99 \%$, E Merck AG, Darmstadt, FRG) and $\mathrm{Al}_{2} \mathrm{O}_{3}$ (Extrapure, $>99995 \%$, Les Rubis Synthetıque des Alpes, Jarrie, France) Because $\mathrm{Cs}_{2} \mathrm{CO}_{3}$ is delıquescent, this material was handled in a glove box in order to be sure that no water was attracted The powders were mixed in the appropr1ate amounts for the total weight to be about $2-5 \mathrm{~g}$ These mixtures were pressed into $250-500 \mathrm{mg}$ pellets and subsequently heated to $900^{\circ} \mathrm{C}$ in air in alumina crucibles $(9999 \%)$ for 24 up to $200 \mathrm{~h}$ During the heating, the contact between the pellet and crucible was minimized to two points The crucibles were taken out of the furnace while still hot and transferred to the glove box to cool down No visible corrosion of the crucibles took place during the experiments. Phases present in the pellet after this calcination procedure were identified by $\mathrm{X}$-ray diffraction (XRD) using CuK $\alpha$ radiatıon In order to prevent reaction between the phases and water vapour from ambient air during $X R D$, the diffractometer was evacuated.

The decomposition of $\mathrm{CaCO}_{3}$ and $\mathrm{Cs}_{2} \mathrm{CO}_{3}$ was measured using thermogravimetric analysis This experiment shows that complete dissociation of the carbonates takes place between $650^{\circ} \mathrm{C}$ and $900^{\circ} \mathrm{C}$

Durıng calcination at $900^{\circ} \mathrm{C}$, the $\mathrm{Cs}_{2} \mathrm{O}$ losses were often considerable This means that the composition changed during the heat treatment By measuring the werght before and after the heat treatment, however, we could calculate the resulting composition The accuracy is good enough for our purpose, but one has to bear in mind that the real compositions might differ and must be checked afterwards

\subsection{A new quasi-ternary compound: $\mathrm{Cs}_{2} \mathrm{O} \cdot 2 \mathrm{CaO}$. $4 \mathrm{Al}_{2} \mathrm{O}_{3}$}

In the first experıments (nos 1-3 in Fig. 2), we found from XRD measurements that together with $\mathrm{Al}_{2} \mathrm{O}_{3}$ and CsA an unknown compound was always formed We developed a new method to locate this compound The principle of this new method is based on the fact that CsA decomposes upon heating at $900^{\circ} \mathrm{C}$, leaving pure $\mathrm{Al}_{2} \mathrm{O}_{3}$ So when we heat mixtures of $\mathrm{CsA}, \mathrm{Al}_{2} \mathrm{O}_{3}$, and the unknown compound for long tımes, $\mathrm{Cs}_{2} \mathrm{O}$ will evaporate out of CsA unt1l no CsA is present When no $\mathrm{Cs}_{2} \mathrm{O}$ 
evaporates from the unknown compound, the resulting compositions will lie on a straight line between $\mathrm{Al}_{2} \mathrm{O}_{3}$ and the unknown compound Thermogravimetric analyses afterwards showed that indeed no $\mathrm{Cs}_{2} \mathrm{O}$ evaporates from the unknown compound Once the composition of the compound was roughly located, we heated mixtures 19-27 (see Fig 2) at $900^{\circ} \mathrm{C}$ until their weights had stabilized The diffraction pattern of mixture 23 showed only peaks of the unknown, white compound Chemical analyses of the sample resulted in a somewhat higher $\mathrm{Cs}_{2} \mathrm{O}$ content than calculated $(340 \mathrm{wt} \% \mathrm{Cs}$, $102 \mathrm{wt} \% \mathrm{Ca}$ and $286 \mathrm{wt} \% \mathrm{Al}) \mathrm{Th} 1 \mathrm{~s}$ corresponds best to $\mathrm{Cs}_{2} \mathrm{O} 2 \mathrm{CaO} \quad 4 \mathrm{Al}_{2} \mathrm{O}_{3}\left(\mathrm{CsC}_{2} \mathrm{~A}_{4}\right)$ The diffraction pattern was measured more accurately using a Guinier camera (Johansson type-Enraf-Nonius BV, Delft, The Netherlands) and from these data the cell parameters were determined (see Table 1) $\mathrm{CsC}_{2} \mathrm{~A}_{4}$ was found to be monoclinic with lattice constants $\quad a=82197 \times 10^{-10} \mathrm{~m}, \quad b=52782 \times$ $10^{-10} \mathrm{~m}, c=77639 \times 10^{-10} \mathrm{~m}$, axial angle $\beta=$ $93487^{\circ}$ and the spacegroup probably $\mathrm{P} 2_{1}$ or $\mathrm{P} 2_{1 / \mathrm{m}}$

Table 1. X-ray powder diffraction data of $\mathrm{Cs}_{2} \mathrm{O} 2 \mathrm{CaO} 4 \mathrm{Al}_{2} \mathrm{O}_{3}$

\begin{tabular}{|c|c|c|c|c|c|c|c|}
\hline$d_{\text {ots }}\left(10^{-10} \mathrm{~m}\right)^{a}$ & $I / I_{1}{ }^{b}$ & $H K L^{\mathrm{c}}$ & $d_{\text {cals }}\left(10^{-10} \mathrm{~m}\right)^{d}$ & $d_{n b s}\left(10^{-10} \mathrm{~m}\right)$ & $J / I_{1}$ & $H K L$ & $d_{\text {cals }}\left(10^{-10} \mathrm{~m}\right)$ \\
\hline 8204 & 13 & 100 & 8205 & 18985 & 25 & 320,222 & 18991 \\
\hline 7747 & 20 & 001 & 7750 & 18811 & 5 & $41 \overline{1}$ & 18812 \\
\hline 5476 & 14 & 101 & 5470 & 18618 & 8 & 321 & 18628 \\
\hline 4438 & 35 & 110 & 4439 & 18186 & 6 & $014,31 \overline{3}$ & 18189 \\
\hline 4362 & 20 & 011 & 4363 & 17963 & 20 & 114 & 17974 \\
\hline 4103 & 8 & 200 & 4102 & 17841 & 8 & 123 & 17845 \\
\hline 3908 & 50 & $11 \overline{1}$ & 3908 & 17689 & 10 & 402 & 17689 \\
\hline 3875 & 35 & 002 & 3875 & 17541 & 3 & 412,114 & 17545 \\
\hline 3803 & 25 & 111 & 3798 & 17336 & 25 & $32 \overline{2}$ & 17345 \\
\hline 3723 & 14 & 201 & 3720 & 17232 & 6 & 313 & 17234 \\
\hline 3588 & 5 & $10 \overline{2}$ & 3589 & 17205 & 6 & 130 & 17203 \\
\hline 34251 & 45 & 102 & 34242 & 17117 & 8 & 223,204 & 17118 \\
\hline 32391 & 50 & 210 & 32390 & 16838 & 6 & 131 & 16840 \\
\hline 31216 & 25 & 012 & 31235 & 16754 & 16 & 131 & 16749 \\
\hline 30404 & 45 & $21 \bar{I}$ & 30409 & 16562 & 20 & $40 \overline{3}, 223$ & 16574 \\
\hline 29678 & 70 & 112 & 29679 & 16192 & 12 & 420 & 16195 \\
\hline 29391 & 50 & 211 & 29387 & 16168 & 12 & 230 & 16170 \\
\hline 29063 & 8 & $20 \overline{2}$ & 29065 & 16012 & 6 & $42 \mathrm{~T}, 032$ & 16014 \\
\hline 28728 & 14 & 112 & 28726 & 15901 & 6 & $23 \bar{I}$ & 15905 \\
\hline 27349 & 6 & 202,300 & 27350 & 15797 & 8 & $13 \overline{2}, 41 \overline{3}$ & 15800 \\
\hline 26396 & 100 & 020 & 26391 & 15753 & 10 & 231 & 15753 \\
\hline 25311 & 3 & 301 & 25311 & 15670 & 20 & 510 & 15669 \\
\hline 25113 & 10 & 120 & 25123 & 15617 & 25 & $024,323+$ & 15618 \\
\hline 24981 & 25 & 021 & 24982 & 15565 & 4 & $31 \overline{4}$ & 15559 \\
\hline 24233 & 8 & 103 & 24221 & 15484 & 3 & 124 & 15482 \\
\hline 23773 & 8 & 121 & 23769 & 15401 & 10 & 105 & 15401 \\
\hline 23200 & 12 & 013 & 23202 & 15206 & 20 & 124,422 & 15205 \\
\hline 22819 & 13 & 311 & 22823 & 14842 & 25 & $22 \overline{4}$ & 14839 \\
\hline 22651 & 5 & $11 \overline{3}$ & 22653 & 14789 & 5 & $502,115+$ & 14788 \\
\hline 22489 & 6 & 203 & 22484 & 14694 & 16 & 422 & 14693 \\
\hline 22195 & 12 & 220 & 22195 & 14540 & 25 & $033,40 \overline{4}$ & 14537 \\
\hline 22003 & 20 & 113 & 22014 & 14485 & 4 & 115 & 14485 \\
\hline 21811 & 20 & 022 & 21812 & 14405 & 3 & $13 \overline{3}$ & 14403 \\
\hline 21519 & 25 & $22 \bar{I}$ & 21525 & 14244 & 25 & $512,50 \overline{3}+$ & 14245 \\
\hline 21282 & 10 & 203 & 21283 & 13676 & 20 & $404,600+$ & 13675 \\
\hline 20902 & 12 & 122 & 20903 & 13403 & 20 & 315 & 13397 \\
\hline 20683 & 25 & $21 \overline{3}$ & 20686 & 13305 & 25 & 125 & 13302 \\
\hline 20511 & 8 & 400 & 20511 & 13248 & 20 & $43 \mathrm{~T}$ & 13248 \\
\hline 20093 & 25 & 312 & 20093 & 13200 & 4 & 040 & 13196 \\
\hline 19737 & 25 & 213 & 19739 & 13014 & 4 & 041 & 13008 \\
\hline 19537 & 8 & 401,222 & 19538 & 12910 & 20 & $225,504+$ & 12912 \\
\hline 19370 & 10 & $004,30 \overline{3}$ & 19376 & 12785 & 3 & 134,432 & 12783 \\
\hline 19117 & 6 & 104,410 & 19118 & 12660 & 20 & 333,602 & 12658 \\
\hline
\end{tabular}

The crystal system is monoclinic with lattıce constants $a=82197 \times 10^{-10} \mathrm{~m}, b=52782 \times 10^{-10} \mathrm{~m}, c=77639 \times 10^{-10} \mathrm{~m}$, and axial angle $\beta=93487^{\circ}$

${ }^{a} d_{\text {obs }}$ is the observed crystal spacing

${ }^{b} I / I_{1}$ is the normalized observed intensity

${ }^{c} \mathrm{HKL}$ are the Miller indices

${ }^{d} d_{\text {calc }}$ is the calculated crystal spacing 


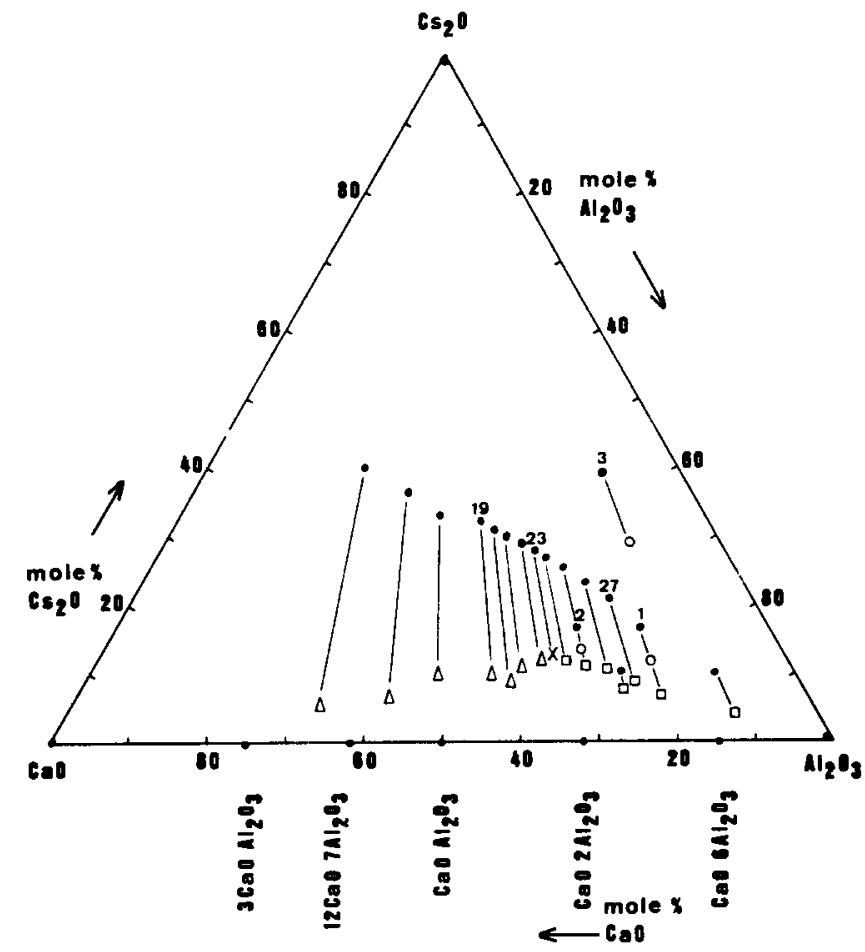

Fig. 2. Representation of some illustrative experıments (O) Starting compositions ( $\mathrm{CsCO}_{3}-\mathrm{CaCO}_{3}-\mathrm{Al}_{2} \mathrm{O}_{3}$ mixtures), $(\mathrm{O})$ $\mathrm{Cs}_{2} \mathrm{O} \quad \mathrm{Al}_{2} \mathrm{O}_{3}, \mathrm{Al}_{2} \mathrm{O}_{3}$ and $\mathrm{Cs}_{2} \mathrm{O} 2 \mathrm{CaO} \quad 4 \mathrm{Al}_{2} \mathrm{O}_{3}$ (samples heated $20 \mathrm{~h}$, weights had not stabilized yet), $(\triangle) \mathrm{CaO}$ and $\mathrm{Cs}_{2} \mathrm{O} 2 \mathrm{CaO} 4 \mathrm{Al}_{2} \mathrm{O}_{3},(\square) \mathrm{Al}_{2} \mathrm{O}_{3}$ and $\mathrm{Cs}_{2} \mathrm{O} 2 \mathrm{CaO} 4 \mathrm{Al}_{2} \mathrm{O}_{3},(x)$ pure $\mathrm{Cs}_{2} \mathrm{O} 2 \mathrm{CaO} \quad 4 \mathrm{Al}_{2} \mathrm{O}_{3}$ One should bear in mind that the end compositions are calculated and could differ a little from reality

Thermogravimetric analysis showed no weight loss up to $1130^{\circ} \mathrm{C}$ (see Fig 3) At this temperature $\mathrm{Cs}_{2} \mathrm{O}$ starts to evaporate very slowly untıl no $\mathrm{Cs}_{2} \mathrm{O}$ is present at $1500^{\circ} \mathrm{C}$ When $\mathrm{CsC}_{2} \mathrm{~A}_{4}$ is left in humid air, it picks up water and loses the crystallınity at the same tıme

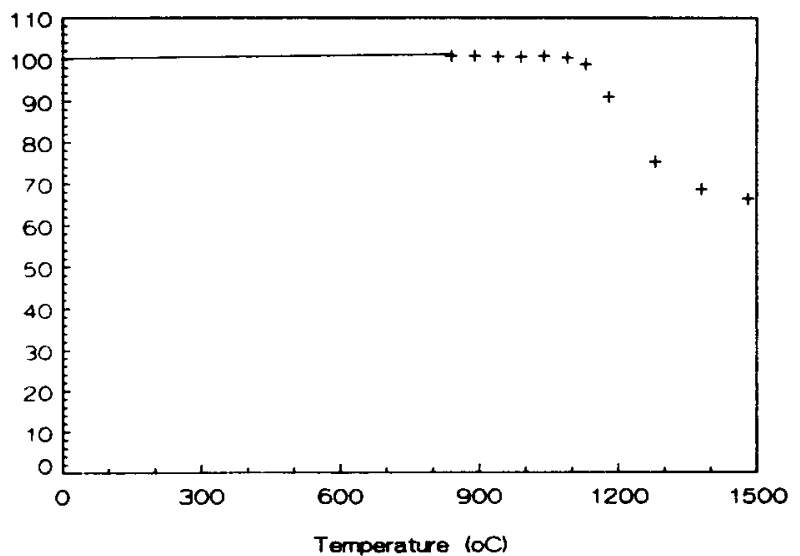

Fig. 3. Thermogravimetric plot of $\mathrm{Cs}_{2} \mathrm{O} 2 \mathrm{CaO} \quad 4 \mathrm{Al}_{2} \mathrm{O}_{3}$ Heating rate is $5^{\circ} \mathrm{C} / \mathrm{min}$ Sample is heated from 20 to $850^{\circ} \mathrm{C}$ and held for $10 \mathrm{~h}$ at that temperature Then it is heated to $900^{\circ} \mathrm{C}$, held for $\mathrm{i} 0 \mathrm{~h}$, etc The marks are the weights after $10 \mathrm{~h}$ at that temperature

\subsection{Compatibility diagram}

The experiments discussed so far, produced information about the $\mathrm{Cs}_{2} \mathrm{O}$-rich part of the compatibility diagram In order to get information about the $\mathrm{CaO}-\mathrm{Al}_{2} \mathrm{O}_{3}-\mathrm{CsC}_{2} \mathrm{~A}_{4}$ triangle, we set up another type of experıment All the known calcium alumınates were synthesized in pure form by high temperature syntheses Samples of these compounds were placed in an alumina crucible also containing $\mathrm{Cs}_{2} \mathrm{CO}_{3}$ and heated for $60 \mathrm{~h}$ at a temperature of $900^{\circ} \mathrm{C} \mathrm{C}{ }_{3} \mathrm{~A}, \mathrm{C}_{12} \mathrm{~A}_{7}$ and $\mathrm{CA}$ react with a large excess $\mathrm{Cs}_{2} \mathrm{O}\left(50 \% \mathrm{Cs}_{2} \mathrm{O}\right.$ in overall composition) forming $\mathrm{CaO}$ and $\mathrm{CsC}_{2} \mathrm{~A}_{4}$ When $\mathrm{CA}_{2}$, on the other hand, reacts with a large excess $\mathrm{Cs}_{2} \mathrm{O}, \mathrm{CsC}_{2} \mathrm{~A}_{4}$ is the only phase detected by XRD The reactions of the calcium aluminates with smaller amounts $\mathrm{Cs}_{2} \mathrm{O}$ can be written as

$$
\begin{aligned}
& \mathrm{C}_{3} \mathrm{~A}+1 \% \mathrm{Cs}_{2} \mathrm{O} \rightarrow \mathrm{CaO}+\mathrm{C}_{3} \mathrm{~A}+\mathrm{CsC}_{2} \mathrm{~A}_{4} \\
& \mathrm{C}_{12} \mathrm{~A}_{7}+1 \% \mathrm{Cs}_{2} \mathrm{O} \rightarrow \mathrm{CsC}_{2} \mathrm{~A}_{4}+\mathrm{C}_{12} \mathrm{~A}_{7}+\mathrm{C}_{3} \mathrm{~A} \\
& \mathrm{CA}+5 \% \mathrm{Cs}_{2} \mathrm{O} \rightarrow \mathrm{CsC}_{2} \mathrm{~A}_{4}+\mathrm{C}_{12} \mathrm{~A}_{7}+\mathrm{CA} \\
& \mathrm{CA}_{2}+5 \% \mathrm{Cs}_{2} \mathrm{O} \rightarrow \mathrm{CA}_{2}+\mathrm{CsC}_{2} \mathrm{~A}_{4}
\end{aligned}
$$

All the results are in good agreement with the diagram proposed by us in Fig 4 The dashed lines between $\mathrm{CsA}$ and $\mathrm{CsC}_{2} \mathrm{~A}_{4}$ are used to indicate that, although CsA is not stable at $900^{\circ} \mathrm{C}, \mathrm{CsA}$ and $\mathrm{CsC}_{2} \mathrm{~A}_{4}$ were found together at the beginning of the experiments $\mathrm{Cs}_{2} \mathrm{O}$ will evaporate out of $\mathrm{CsA}$ when

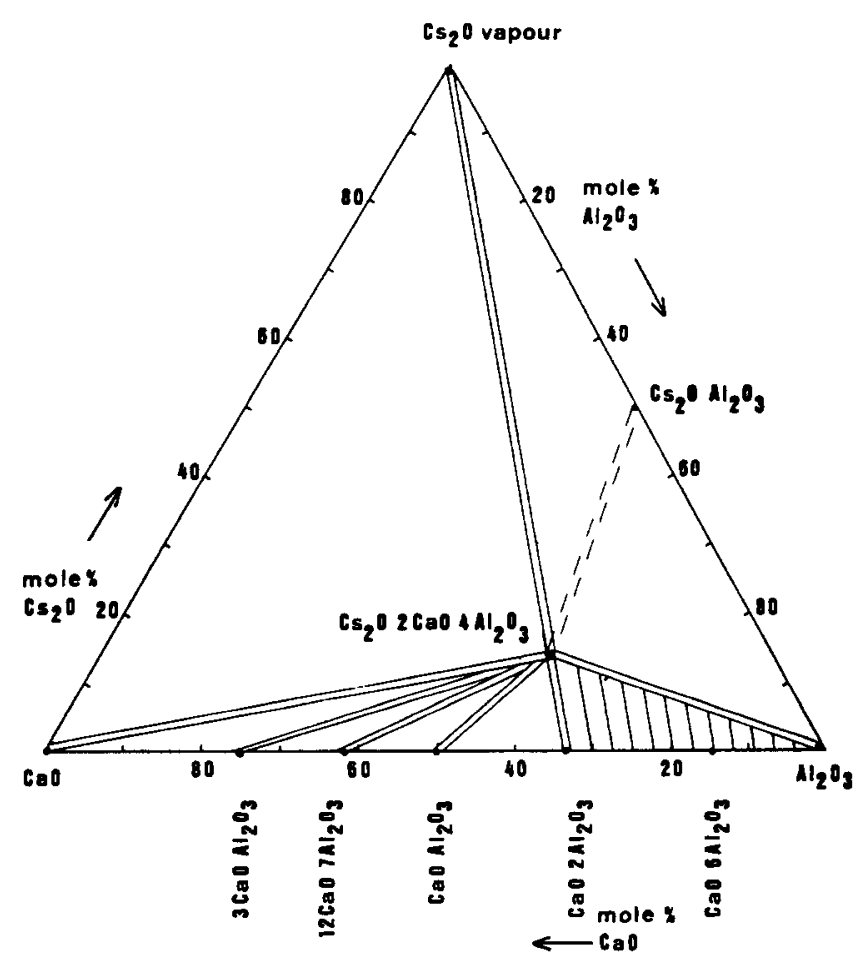

Fig. 4. Compatibility diagram at $900^{\circ} \mathrm{C}$ in the $\mathrm{Cs}_{2} \mathrm{O}-\mathrm{CaO}$ $\mathrm{Al}_{2} \mathrm{O}_{3}$ system The shaded area is not filled in because it is not completely clanfied 
heated for longer tımes in an open system, leaving $\mathrm{Al}_{2} \mathrm{O}_{3}$ and evaporated $\mathrm{Cs}_{2} \mathrm{O}$

In the $\mathrm{Al}_{2} \mathrm{O}_{3}$-rich part of the diagram, some problems arose The results of the $\mathrm{CA}_{6}+\mathrm{Cs}_{2} \mathrm{CO}_{3}$ experiment could not be understood on the basis of the compatibility diagram we constructed When $\mathrm{CA}_{6}$ was heated together with $\mathrm{Cs}_{2} \mathrm{CO}_{3}$, we found that an amorphous material had been formed This experiment neither confirms nor contradicts the proposed diagram In order to verify the stability of $\mathrm{CA}_{6}$, this compound was heated for $1000 \mathrm{~h}$ at $900^{\circ} \mathrm{C}$ No signs of decomposition were found On the other hand $\mathrm{CA}_{6}$ could not be formed within $1000 \mathrm{~h}$ at $900^{\circ} \mathrm{C}$ out of a $\mathrm{CaCO}_{3}-\mathrm{Al}_{2} \mathrm{O}_{3}$ mixture Thus, no conclusion about the stability of $\mathrm{CA}_{6}$ at $900^{\circ} \mathrm{C}$ could be drawn from these experiments This part of the diagram is not completely understood and should therefore be studied more closely

\section{Discussion}

All the experimental results we obtained during this study are in good agreement with the compatibility diagram proposed by us In spite of this, we should also make some critical remarks

In the $\mathrm{Al}_{2} \mathrm{O}_{3}$-rich part of the diagram, two compounds are reported in literature which we did not find during our own investigations Only once has it been reported that $\mathrm{CsA}_{11}$ can be formed after a year heating at $700^{\circ} \mathrm{C}$ and that this compound is stable up to $1050^{\circ} \mathrm{C}$ We decided to leave it out of the diagram for the reasons that the compound was only reported once and because it was never found during our own investigations

The problem with $\mathrm{CA}_{6}$ is well known It is not formed at $900^{\circ} \mathrm{C}$ but it is believed to be stable at that temperature It is known that $\mathrm{CaO}$ segregrates on the grain boundaries of polycrystalline $\mathrm{Al}_{2} \mathrm{O}_{3}$ (Ref 21) probably leading to the formation of $\mathrm{CA}_{6}$ This is the reason why it is important to know the behaviour of this compound when it is exposed to $\mathrm{Cs}_{2} \mathrm{O}$ For this reason we did not want to leave $\mathrm{CA}_{6}$ out of the diagram, although we do not know the exact phase relations

As mentioned above, $\mathrm{CaO}$ segregates to the grain boundaries of $\mathrm{Al}_{2} \mathrm{O}_{3}$ As shown in the experiments, all the calcium aluminates react with $\mathrm{Cs}_{2} \mathrm{O}$ to form $\mathrm{CsC}_{2} \mathrm{~A}_{4}$ This means that even without knowing in which form (phase) $\mathrm{CaO}$ is present on the grain boundaries, we can predict from the diagram proposed by us that the grain boundaries will be corroded by $\mathrm{Cs}_{2} \mathrm{O}$ From these results one may conclude that it is better to avoid $\mathrm{CaO}$ as a sinter and for alumina that is to be used in Cs containing atmospheres

\section{Acknowledgment}

The authors gratefully acknowledge E J Sonneveld, Technisch Physische Dienst, PO Box 155, Delft, The Netherlands, for determining the cell parameters

\section{References}

1 Odoj, R \& Hılpert, K, Mass spectrometric study of the evaporation of crystalline compounds in the cesium oxidealuminum oxide-silicon oxide $\mathrm{Cs}_{2} \mathrm{O}-\mathrm{Al}_{2} \mathrm{O}_{3}-\mathrm{SlO}_{2}$ system 1 The synthetic compound cesium aluminosilicate ( $\left.\mathrm{CsAlS}_{2} \mathrm{O}_{6}\right)$ and the mineral pollucite High Temp-High Pressures, 12 (1980) 93-8

2 Solov'eva, T V. Moroz, I Kh \& Vydrık, G A, X-ray diffraction study of the synthesis of aluminum cesium disilicate Russ J Inorg Chem, 15 (1970) 909-11

3 Wolff, $L \mathrm{R}$, Heinen, $\mathrm{C} \mathrm{J} \&$ van de Wouw, $\mathrm{G} \mathrm{P}, \mathrm{Cr}_{2} \mathrm{O}_{3}$, $\mathrm{Al}_{2} \mathrm{O}_{3}-\mathrm{Mo}$ as a thermionic emitter material High TempHtgh Pressures, 13 (1981) 69-77

4 Gubbels. G H M, Wolff, L R \& Metselaar, R, Electron emission microscope measurements on cermet electrodes for thermionic converters Solıd State lonics, 16 (1985) $47-54$

5 Gubbels, G H M, Wolf, L R \& Metselaar, R, A thermionic energy converter with polycrystalline molybdenum electrodes $J$ Appl Phys, 64(3) (1988) 1508-12

6 Wagner, P \& Coriell, S R, High-temperature compatıbility of cesium gas with some dielectrics Rev Sa Instr, 30(1959) 937-8

7 Slıvka, M J . A study of cesium vapor attack on thermıonıc converter construction materials Advanced Energy Converston, 3 (1963) 157-65

8 Hargreaves. F, Mayo, G T J \& Thomas, A G, A study of the long-term compatibility of thermionic converter materials with caesium $J$ of Nucl Mater, 18(1966) 212-18

9 Britt. E J, Desplat, J L, Gulden, T, Chin, J \& Cone, V, Long-life insulators for in-core thermıonics In Proceedings of the 20th Intersociety Energy Conversion Engineering Conference Society of Automotive Engineers, Inc, 400 Commonwealth Drive, Warrendale, PA 15096, 1985, pp 3499-3 512

10 Smith, R G, Hargreaves, F, Mayo, G T J \& Thomas, A $\mathrm{G}$, The compatıbility of thermionic converter matenals with cesium $J$ Nucl Mater, 10 (1963) 191-200

11 Higgens, J K, Reaction of alumina with cesium vapor Trans Brtt Ceram Soc, 65 (1966) 643-59

12 Grossman, $\mathrm{L} N$, Interactions in the system $\mathrm{Cs}_{(\mathrm{g} 1)}-\mathrm{SiO}_{2}$ $\mathrm{Al}_{2} \mathrm{O}_{3}$ Ret Int hautes Temper Refract, 16 (1979) 255-61

13 Langlet G, Centre d'Etudes Nuclearres de Saclay Rapport CEA-R-3853, 1969

14 Semenov, N N, Merkulov, A G \& Vorsina, I A, The synthesis and study of the compounds of the $\mathrm{Cs}_{2} \mathrm{O}-\mathrm{Al}_{2} \mathrm{O}_{3}$ system Ser Khım Nauk, 1(2) (1967) 75-83

15 Barkova, F F, Pysına, N E \& Strukulenko, N A, Rare alkalı elements Sb Dokl naII Vsesojuznom Sov NovosibIrsk Nauka 1967

16 Nurse, $\mathrm{R}$ W, Welch, J H \& Majumdar, A J, The CaO$\mathrm{Al}_{2} \mathrm{O}_{3}$ system in a molsture-free atmosphere Trans Brit Ceram Soc, 64 (1965) 409-17

17 Chatterjee, A K \& Zhmoidın, G I, The phase equilibrium diagram of the system $\mathrm{CaO}-\mathrm{Al}_{2} \mathrm{O}_{3}-\mathrm{CaF}_{2} J$ Mater $\mathrm{Sct}, 7$ (1972) 93-7 
18 Kohatsu, I \& Brindley, G W, Solıd state reactıons between $\mathrm{CaO}$ and $\alpha-\mathrm{Al}_{2} \mathrm{O}_{3} Z$ Phys Chem, 60 (1968) 79-89

19 Verwey, $\mathbf{H} \&$ Saris, C M P M, Phase formation in the system $\mathrm{Na}_{2} \mathrm{O} \quad \mathrm{Al}_{2} \mathrm{O}_{3}-\mathrm{CaO} \quad \mathrm{Al}_{2} \mathrm{O}_{3}-\mathrm{Al}_{2} \mathrm{O}_{3}$ at $1200^{\circ} \mathrm{C}$ in air $J$ Am Ceram Soc, 69 (1986) 94-8
20 Weisweıler, W \& Ahmed, S J, Kinetics of the solid state reactions in the system CaO- $\mathrm{Al}_{2} \mathrm{O}_{3}$ Zem-Kalk-Gips, 33(2) (1980) 84-9

21 Franken, P E C \& Gehrng, A P, Grain boundary analysis of magnesia-doped alumina $J$ Mater $S c l, 16(1981) 384-8$ 